\title{
Detecting of virulence factors COWP gene and CP15 gene for Cryptosporidium parvum by polymerase chain reaction (PCR)
}

\section{Fatima Ibrahim Mohammad}

AL-Qadisiya University/college of science

Fatima.mohammad@qu.edu.iq

Received:-15/1/2017

Accepted:-20/2/2017

\begin{abstract}
The

present study aims to diagnose the parasite Cryptosporidium parvum isolated stool samples of patients to reviewers Diwaniya Teaching Hospital and Maternity Hospital and Children in the province of Diwaniyia .The infected ranged from the age less than one year to 12 years at the period from beginning of May to the end of November 2016.
\end{abstract}

110 samples stool were collected and the number of infected samples is (30) sample. After examining samples in direct examination of the sample wet method.

The study included verification of virulence factors Cryptosporidium Oocyst Wall Protein (COWP), Surface Protein of Sporozoite (CP15) in parasite using conventional PCR technique.

The study showed that age groups less than one year were the highest infection rate $(43.3 \%)$ while the age group of (9-12) years showed lowest infection rate (10\%) with a significant difference between them, infection rate in females (56.6\%) was higher than males $(43.3 \%)$ but did not reach the level of significant.

These ratios also appeared in the rural areas are the highest (63.3\%) compare with urban areas $(36.6 \%)$ with a significant difference between them.

DNA was extracted from positive stool samples and then after amplified using virulence factors of parasite COWP gene (281bp), CP15 gene (230bp) and the results appeared present these factors in all positive samples of C.parvum.

Key words: Cryptosporidium parvum, COWP, CP15, PCR

Physiology Classification QR1-502-71 


\section{Introduction}

Protozoan parasites of the genus cryptosporidium infect the gastrointestinal tract of many animals species and cause cryptosporidiosis (1).this parasite causing mild- to severe diarrhea depending on the host's immune status, the infection can spread to extraintestinal, hepatobiliary, pancreatic and pulmonary regions of the body leading to chronic disease and wasting (2). the infection can be a cute and self-limiting illness in immunocompetent patients cryptosporidiosis can become a chronic and life- threatening disease in immunocompromised pateints $(3,4)$. the infection of cryptosporidiosis occurs by the faecal oral route and contamination water with infective oocysts, oocysts release sporozoite which invade the intestinal epithelium cells predominantely localized to the jejunum and ileum $(5,6)$.

Virulence factors for cryptosporidium have been identified as genes involved in the initial

\section{Materials and Methods}

\section{Sample collection}

110 human stool samples were collected from patients microbiology laboratory to Diwaniya teaching Hospital and Maternity

\section{Microscopic examination}

Stool samples examined by preparation of direct wet smear mix a drop of saline solution on a glass slide with a small sample

\section{Genomic}

Genomic DNA was extracted from feces samples by using (Stool DNA extraction Kit, Bioneer. Korea). The extraction was done according to company instructions by using stool lysis protocol method with Proteinase

\section{Polymerase chain reaction}

PCR assay was performed for detection of virulence factors genes (Cryptosporidium Oocyst Wall Protein (COWP) gene and interaction processes of cryptosporidium oocysts and sporozoites with host epithelial cells including excystation, gliding motility, attachment, invasion, parasitophorous vacuole formation, intracellular maintenance and host cell damage $(7,8)$. Surface protein of sporozoite (CP15) is expressed by the infective sporozoite and merozoite stages (9) its involved in the invasion and the host immune response to infection $(10,11,12)$ and its apparent role in the invasion of mammalian cells by C.parvum sporozoites (13).

Cryptosporidium Oocyst Wall Protein (COWP) gene has been localised in the wall forming bodies of early and late macrogametes and the inner layer of the oocyst wall, there are at least two alleles of the COWP gene in the C.parvum population, one associated only with the human host, the other with both animals and humans(14).

Hospital and Children, and then transport to laboratory and stored in freeze.

of feces using wooden sticks, then put the slide cover and examine using microscope under power zoom 10X and 40X.

\section{Extraction}

K. After that, the extracted gDNA was checked by Nanodrop spectrophotometer, and then stored at $-20 \mathrm{C}$ at refrigerator until used in PCR amplification.

Surface Proteins of Sporazoite (CP15) of Cryptosporidium parvum. The primers were designed in this study using NCBI-Genbank 
data base (COWP GenBank: DQ388390.1, CP15 GenBank: U22892.1) by Primer3plus.
The primers were provided by (Bioneer company . Korea). As following table (1):

Table (1): prefixes of C.parvum used in the study with the nucleotide sequence (PCR reaction).

\begin{tabular}{|c||c||c||}
\hline \multirow{2}{*}{ Primers } & Sequence & Amplicon \\
\hline \hline \multirow{2}{*}{ COWP gene } & CCAGAATGTCCTCCAGGCAC & \multirow{2}{*|}{$281 \mathrm{bp}$} \\
\cline { 2 - 3 } & GTATATCCTGGTGGGCAGACC & \\
\hline \multirow{2}{*}{ CP15 gene } & CACTCGATTGTGTCTCCCCC & \multirow{2}{*}{$230 \mathrm{bp}$} \\
\cline { 2 - 3 } & TTCTTGGGGGTGGTTGGAAG & \\
\hline
\end{tabular}

Then PCR master mix was prepared by using (AccuPower ${ }^{\circledR}$ PCR PreMix kit. Bioneer. Korea). The PCR premix tube contains freeze-dried pellet of (Taq DNA polymerase $1 \mathrm{U}$, dNTPs $250 \mu \mathrm{M}$, Tris-HCl (pH 9.0) $10 \mathrm{mM}$, $\mathrm{KCl} 30 \mathrm{mM}, \mathrm{MgCl} 21.5 \mathrm{mM}$, stabilizer, and tracking dye) and the PCR master mix reaction was prepared according to kit instructions in $20 \mu 1$ total volume for each gene independent by added $5 \mu 1$ of purified genomic DNA and $1.5 \mu 1$ of 10 pmole of forward primer and $1.5 \mu 1$ of 10pmole of reverse primer, then complete the PCR premix tube by deionizer PCR water into $20 \mu \mathrm{l}$ and briefly mixed by Exispin vortex Results centrifuge (Bioneer. Korea). The reaction was performed in a thermocycler (Mygene, Bioneer. Korea) by set up the following thermocycler conditions; initial denaturation temperature of $95{ }^{\circ} \mathrm{C}$ for 5 minutes followed by 30 cycles at denaturation $95^{\circ} \mathrm{C}$ for 30 seconds, annealing $60^{\circ} \mathrm{C}$ for 30 seconds, and extension $72^{\circ} \mathrm{C}$ for $30 \mathrm{sec}$. minute and then final extension at $72^{\circ} \mathrm{C}$ for 5 minutes. The PCR products were examined by electrophoresis in a $1.5 \%$ agarose gel, stained with ethidium bromide, and visualized under UV Transilluminator.

\section{Prevalence of Cryptospridium spp. according to a microscopic examination}

The results of the current study, depending on the method of direct wet smear that there are 30 samples out of 110 samples were positive to infection of the parasite as the shown in the figure (1): 


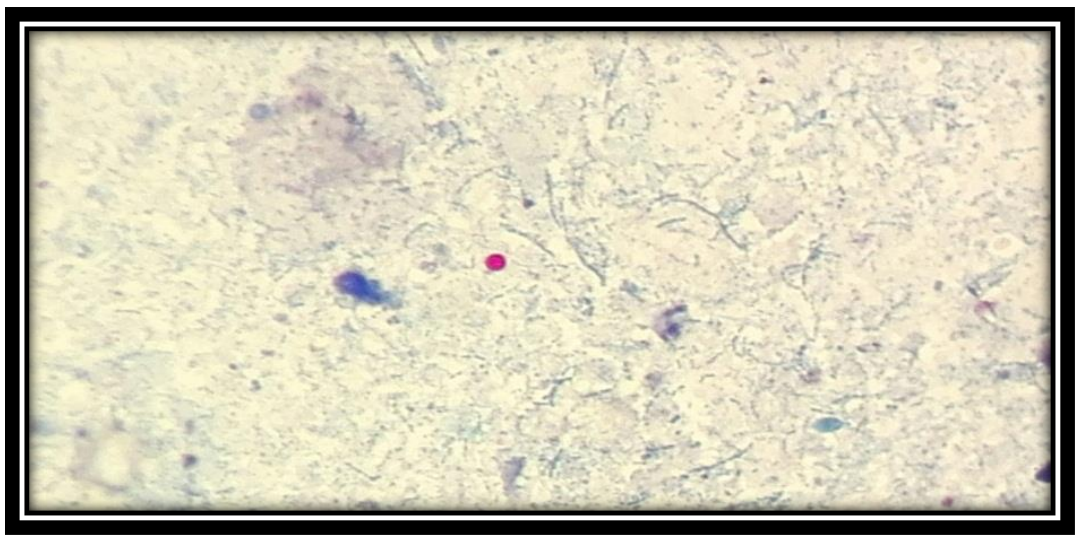

Figure (1): Oosyst of C.parvum

\section{2. prevalence of $C$.parvum according to the sex}

Results of the study showed that the percentage of female infection with parasite was $56.6 \%$ compared to males where the percentage of infection was $43.3 \%$ but it didn't reach the level of significance at $p>0.05$. table (2):

Table (2): prevalence of C.parvum according to the sex

\begin{tabular}{|c||c||c|}
\hline Sex & The number of patients & $\%$ \\
\hline Males & 13 & $43.3 \mathrm{a}$ \\
\hline \hline Females & 17 & $56.6 \mathrm{a}$ \\
\hline
\end{tabular}

chi- square value $\left(\mathrm{X}^{2}\right)=1.771$

\section{3. prevalence of $C$.parvum according to the age groups}

Results of the current study showed that the rate of infection at the age of less than one year $(43.3 \%)$ was the highest and lowest infection at the age of (9-12) years with a significant difference at $p>0.05$. table (3):

Table (3): prevalence of $C$.parvum according to the age group

\begin{tabular}{|c|c|c|}
\hline Age groups & $\begin{array}{c}\text { The number of infected } \\
\text { patients }\end{array}$ & $\%$ \\
\hline Less than one year & 13 & $43.3 \mathrm{a}$ \\
\hline \hline $1-4$ & 9 & $30 \mathrm{a}$ \\
\hline $5-8$ & 5 & $16.6 \mathrm{~b}$ \\
\hline $9-12$ & 3 & $10 \mathrm{~b}$ \\
\hline
\end{tabular}

Chi-square value $\left(\mathrm{X}^{2}\right)=26.244$ 


\section{4. prevalence of $C$.parvum according to the nature of residence}

The results of the current study showed that the infection rate in rural areas is the highest $(63.3 \%)$ compared to the urban areas $(36.6 \%)$ the lowest rate of infection with a significant difference at $p>0.05$ table (4):

Table (4): prevalence of $C$.parvum according to the nature residence

\begin{tabular}{|c|c|c|}
\hline Nature of residence & The number of patients & $\%$ \\
\hline \hline Urban areas & 11 & $36.6 \mathrm{a}$ \\
\hline \hline Rural areas & 19 & $63.3 \mathrm{~b}$ \\
\hline
\end{tabular}

Chi-square value $\left(\mathrm{X}^{2}\right)=7.136$

* similar letters means non-significant differences at the level of probability of 0.05 using test $\mathrm{X}^{2}$.

*Different letters means significant differences at the level of probability of 0.05 using test $\mathrm{X}^{2}$.

\section{Molecular study}

Results of molecular test PCR showed that all positive samples for the parasite C.parvum $(100 \%)$ contain virulence factors studied which were Cryptosporidium Oocyst Wall Protein and Surface Protein of sporozoite as the figure show (2 and 3) the molecular weight of the
COWP factor (281bp) percentage $(100 \%)$ and the molecular factor of the CP15 (230bp) percentage $(100 \%)$ and were examined by electrophoresis in a $1.5 \%$ agarose gel and stained with ethidium bromide and examined using UV transilluminator.

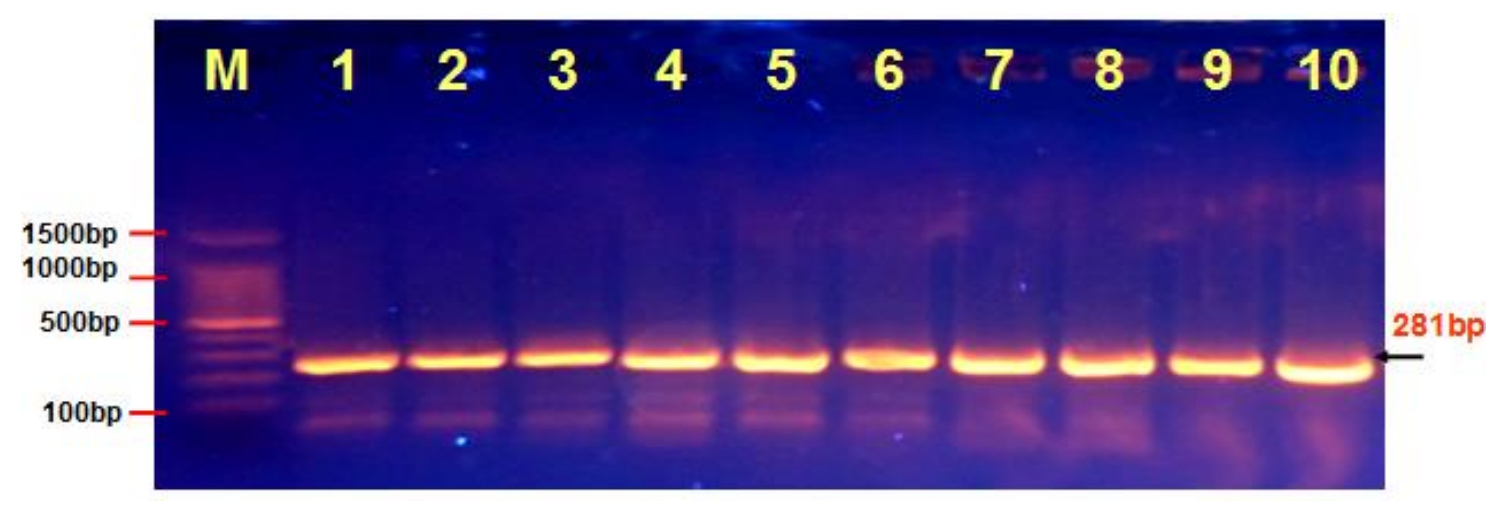

- Figure (2): Agarose gel electrophoresis image that show the PCR product of Cryptosporidium oocyst wall protein (COWP) gene in Cryptosporidium parvum positive isolates. Where M: Marker (1500-100bp), lane (1-10) some positive $C$. parvum at 281bp PCR product size. 


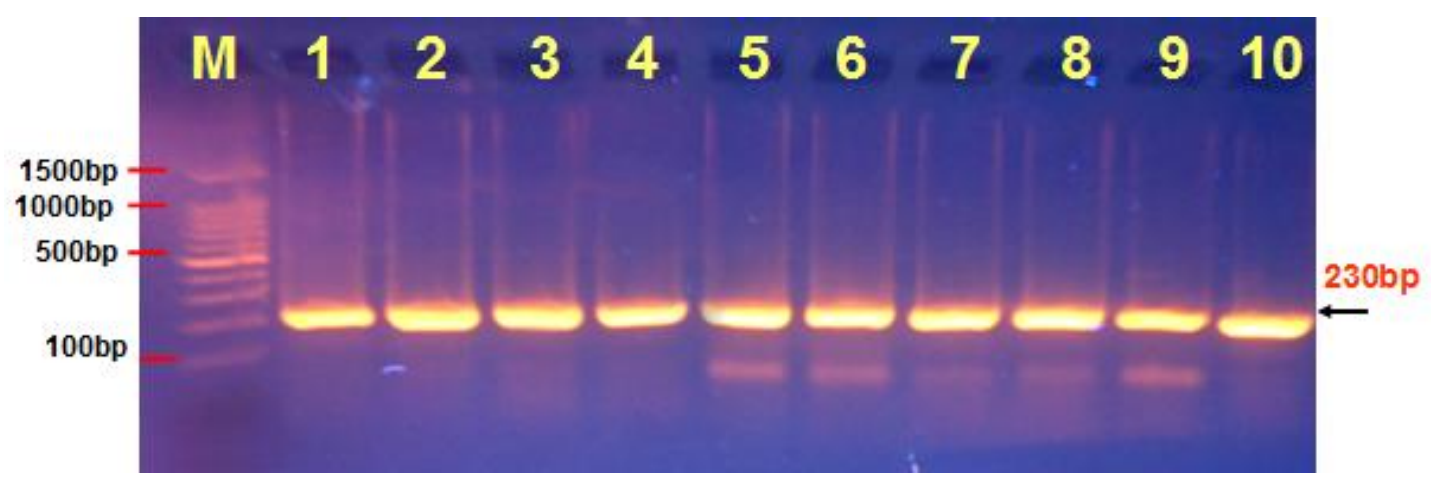

Figure 3: Agarose gel electrophoresis image that show the PCR product of Cp15 surface proteins of sporazoite in Cryptosporidium parvum positive isolates. Where M: Marker (1500-100bp), lane (1-10 ) some positive $C$. parvum at 230bp PCR product size.

\section{Discussion}

Cryptosporidium parvum is an intracellular protozoan parasite of the family Cryptospridiidae and phylum Apicomplexa (15). This disease occurs worldwide and is ubiquitous in the environment (16). Cryptosporidiosis is in the top five most common causes of infections diarrhea around the globe (17).

Results of the current study showed that the parasite Cryptosporidium parvum

The relationship between spread of disease in both sexes is non significant relationship, the percentage of infection in females reached $(56.6 \%)$ while in males $(43.3 \%)$ this is consistent with (19).

The results of this study that the parasite is most prevalent in rural areas $(63.3 \%)$ and the lowest rate in urban areas (36.6\%) and this is consistent with (20) and the reason due to presence of grazing such as cows and sheep in rural areas compared with urban areas at least interested in raising cattle and sheep.

Results proved presence COWP factor in all positive samples for infection affected all age groups but the infection rate in less than one year old $(43.3 \%)$ was the highest and recorded less injured rate in the age group (9-12) years and the reason for this due to the immune system is incomplete at the age of less than one year as well as the left breast feeding to artificial feeding and ignorance many mothers things sterilization and cleanliness of the water and milk bottles this is consistent with (18).

percentage $100 \%$, its higher than of infection rate that recorded (14) reached 98\% that showed existence of least two alleles of the COWP gene in the C.parvum one associated only with the human host and the other with both animals and humans, and supports that cryptosporidiosis in humans is not necessarily a zoonosis(21).

The study proved presence CP15 factor in all positive samples for infection percentage $100 \%$ and this consistent with (22), this factor it's apparent role in the invasion of mammalian cells by C.parvum sporozoites (13). 


\section{Refrences}

1.O'Hara,S.P. and Chen,X.M. (2011). The cell biology of Cryptosporidium infection. Microbes.Infect.13,721-730.

2. Leitch ,G.J. and He,Q.(2012). Cryptosporidiosis-an overview. J Biomed Res; 25: 1-16.

3. Kurniawan, A.; Dwintasari ,S.W.; Connelly, L.; Nichols, R.A.; Yunihastuti, E.; Karyadi, T. and Djauzi,S.(2013). Cryptosporidium species from human immunodeficiency-infected patients with chronic diarrhea in Jakarta, Indonesia. Ann Epidemiol; 23: 720-723.

4. Elwin, K.; Hadfield, S.J.; Robinson, G. and Chalmers, R.M.(2012). The epidemiology of sporadic human infections with unusual cryptosporidia detected during routine typing in England and Wales, 2000- 2008. Epidemiol Infect; 140: 673-683.

5. Baldursson, S. and Karanis, P.(2011). Waterborne transmission of protozoan parasites: review of worldwide outbreaks - an update 2004-2010. Water Res. 45 (20),66036614.

6. Chappell, C.L.; Okhuysen, P.C.; LangerCurry, R.; Widmer, G.; Akiyoshi, D.E. and Tanriverdi, S. (2006). Cryptosporidium hominis: experimental challenge of healthy adults.Am. J. Trop. Med. Hyg. 75, 851-857.

7. Fayer, R.; Orlandi, P. and Perdue, M. L. (2009). "Virulence factor activity relationships for hepatitis E and Cryptosporidium." J Water Health. 7 Suppl 1: S55-63.

8. Wanyiri, J. and Ward, H. (2006). "Molecular basis of Cryptosporidium-host cell interactions: recent advances and future prospects." Future Microbiol. 1: 201-8.

9. Jenkins, M.C. and Fayer, R. (1995). Cloning and expression of cDNA encoding an antigenic Cryptosporidium parvum protein. Mol. Biochem. Parasitol. 71, 49-52.

10. Moss, D.M.; Chappell, C.L.; Okhuysen, P.C.; DuPont, H.L.; Arrowood, M.J.;
Hightower,A.W.(1998). The antibody response to 27-, 17-, and 15-kDa Cryptosporidium antigens following experimental infection in humans. J. Infect. Dis. $178,827 \mathrm{e} 833$.

11. Sturbaum, G.D.; Jost, B.H.and Sterling, C.R. (2003). Nucleotide changes within three Cryptosporidium parvum surface protein encoding genes differentiate genotypeI from genotype II isolates. Mol. Biochem. Parasitol. $128,87-90$.

12. Tilley, M. and Upton, S.J.(1994). Both CP15 and CP25 are left as trails behind gliding sporozoites of Cryptosporidium parvum (Apicomplexa). FEMS Microbiol. Lett. 120,275-279.

13.Manque, Particio A.; Tenjo, Fernando; Woehlbier, Ute; Lara, Ana M.; Serrano, Myrna G.;Xu, Ping; Alves, Joao M.; Semeltz, Ronaldo B.; Conrad, Danial $H$ and Buck, Gregory A.(2011). Identification and Immunological characterization of three potential vaccinogens agnaist Cryptosporidium species, Clinical and Vaccine Immunology, 18(11):1796-102.

\section{Spano,R.;Purl,C.;Ranucci,L.;}

Putignani,L. and Crisanti,A.(1997). Colning of the entire COWP gene ofCryptosporidium parvum and ultrastructural localization of the protein during sexual stage development. Parasitology 114, 427-437.

15.Fayer, R., Morgan, U., \& Upton, S. J. (2000). Epidemiology of Cryptosporidium: Transmission, detection and identification. International Journal for Parasitology, 30(1213), 1305-1322.

16.Xiao, L., and Cama, V. (2007). Cryptosporidium. In P. R. Murray (Ed.), Manual of Clinical Microbiology .Washington D.C.: ASM Press. $9^{\text {th }}$ ed.,pp.2122-2132.

17.Boatright, D. T., and Greenfield, R. A. (2005). Bioterrorism and Threats to Water Safety: Cholera and Cryptosporidiosis. In M. S. Bronze, \& R. A. Greenfield (Eds.), 
Biodefense: Principles and Pathogens. Norfolk UK: Horizon Bioscience: pp.587-617.

18.Areeshi,M.Y.; Beeching,N.J. and Hart,C.A.(2007).Cryptosporidiosis in saudi Arabia and neighbouring countries. Ann. Saudi. Med.27(5):325-332.

19.Casemore, D. P.(1990). "Epidemiological aspect of human Cryptosporidiosis". Special Article” Epidemiol. Infect.,Vol. 104 , pp. 1-28.

20. Okafor, J. I. and Okunji, P. O.(1994)." Cryptosporidiosis in patients with diarrhoea in five hospitals in Nigeria". J. Nigeria. J. Commun. Dis. 26( 2),pp: 75-81.

\section{Awad-EL-}

Kariem,FM.;Robinson,H.A.;Dyson,D.A.;Ev ans,D.;Wright,S.;Fox,M.T. and Mc

Donald,V.(1995). Differentiation between human and animal strains Cryptosporidium parvum using isoenzyme typing. Parasitology 110: 129-132.

22.Yang, R.; Elankumaran,Y.; Hijjawi,N. and Ryan,U. (2015). Validation of cell-free culture using scanning electron microscopy (SEM) and gene expression studies.Experimental Parasitology. 153:55-62. 


\section{تحديد عوامل الضراوة COWP gene و CP15 gene و لطفيلي الابواغ الخبيئة}

(PCR) باستخلام تقنية تفاعل سلسلة البلمرة Cryptosopridium parvum

$$
\text { فاطمة إبرا اهيم محمد }
$$

Fatima.mohammad@qu.edu.iq

$$
\text { تاريخ القبول :- 2017/2/20 }
$$

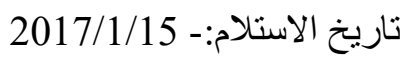

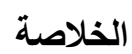

تهدف الدراسة الحالية الى تشخيص طفيلي الابواغ الخبيئة Cryptosporidium parvum المعزول من عينات براز المرضى المراجعين الى مستشفى الديوانية التعليمي ومستشفى الولادة والأطفال في محافظة الديوانية. تراوحت اعمار المصابين (اقل من سنة - 12سنة) للفترة الواقعة من الأول من شهر آيار ولغاية نهاية شهر تشرين الثاني للعام

2016. تم جمع 110 عينة براز وكان عدد العينات المصابة 30 عينة بعد فحص العينات بطريقة الفحص المباشر للعينة الرطبة .

تضدنت الدراسة التحري عن عوامل الضراوة Cryptosporidium Oocyst Wall Protein (COWP) و Surface Protein of . conventional PCR في الطفيلي باستخدام طريقة sporozoite (CP15)

أظهرت الدراسة ان الفئات العمرية اقل من سنة كانت اعلى نسبة إصابة حيث بلغت (43.3\%) بينما الفئات العمرية من (9-12) سنة اظهرت اقل نسبة إصابة وبلغت (10\%) مع وجود فروقات معنوية بينها وكانت نسبة إصابة الاناث (56.6) وهي اعلى من نسبة إصابة الذكور (43.3\%) الا انها لم تصل الى مستوى المعنوية كما ظهرت هذه النسب في المناطق الريفية هي الأعلى (63.3\%) بالمقارنة مع المناطق الحضرية (36.6\%) مع وجود فروقات معنوية بينها.

تم مضاعفة الحامض النووي المستخلص من العينات الموجبة باستخدام عوامل الضراوة للطفيلي COWP (281bp) و (230bp)

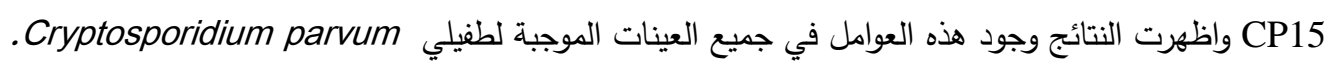
الكلمات المفتاحية: PCR, CP15, COWptosporidium parvum ,COWP. 